\title{
CANADIAN ASSOCIATION OF LAW LIBRARIES 1981 ANNUAL MEETING
}

The annual meeting of the Canadian Association of Law Libraries will take place at the Queen's University in Kingston, Ontario, on May 19-22, 1981. The tentative program includes presentations on "Satisfaction and Stress in the Law Librarian's Occupation", "Labor-Current Trends and Bibliography", "International Organizations-Their Structure and Documents", and "Library Automation", as well as meetings of various interest groups. The annual meeting will be preceded by a workshop on the use of United States legal materials.

For more information contact: Irene Bessette, Queen's University, Law Library, Union Street, Kinston, Ontario K7L 3N6, CANADA.

\section{DOCUMENTS IN MICROFICHE}

In the course of its broader program to make important out-of-print United States documents available to researchers, Princeton Datafilm, Inc., has reproduced in microfiche the Collected Publications of the United States Advisory Commission on Inter-Governmental Relations. This collection includes the Commission's " $A$ " series policy reports, the "M" series information reports and staff analyses, " $S$ " series public opinion surveys, and other publications. The documents cover almost twenty years of the Commission's activities from 1961 to 1979 on a variety of topics relative to the cooperation between federal and state government agencies and the distribution of federal funds for such purposes.

The microfiche collection consists of some 425 good quality silver halide microfiche with negative polarity conforming to the 98 -image NMA standard of $105 \mathrm{~mm} \times 148 \mathrm{~mm}$ with a reduction ratio of 20 to $24: 1$. The microfiche headers contain full bibliographic citations on easily recognizable color stripes.

In order to make the materials more easily retrievable Princeton Datafilm, Inc., has also compiled a detailed index to the documents. Published in hard copy and consisting of twenty-two finely printed pages the index provides subject and keyword access to the documents, as well as an alternative reference to their official titles. The index represents a salutary advancement in the improvement of editorial techniques to enhance and facilitate the use of micromaterials.

For further information contact: Princeton Datafilm, Inc., Box 2231, Princeton, New Jersey 08540, U.S.A.

\section{NEW SOVIET FUNDAMENTALS FOR THE JUDICIAL SYSTEM}

On June 25, 1980, the Supreme Soviet of the USSR promulgated a new text of the Fundamentals of Legislation on the Judicial System of 